\title{
Upgrading Italy's Industrial Capacity: Industry 4.0 across Regions and Sectors
}

\author{
Valeria Cirillo* \\ University of Bari Aldo Moro
}

\section{Lucrezia Fanti}

Università Cattolica del Sacro Cuore (Unicatt)

\section{Andrea Mina}

Sant'Anna School of Advanced Studies University of Cambridge

\section{Andrea Ricci}

INAPP

\begin{abstract}
How are Industry 4.0 investments distributed across Italian regions and sectors? Which are the main drivers of diffusion? To address these questions, in this study we exploit rich firm survey data on the adoption of the new digital technologies and examine their adoption patterns. On the one hand, we produce novel insights into the drivers of structural change in the Italian economy, and on the other, we provide evidence on the technological upgrading of Italy's production capacity that is relevant for policy. The results of econometric tests on region-sector pairs indicate that corporate governance characteristics, innovation patterns and type of industrial relations are significant predictors of the uneven regional and sectoral distribution of Industry 4.0 investments.
\end{abstract}

Come sono distribuiti gli investimenti di Industria 4.0 nelle regioni e nei settori italiani? Quali sono i principali driver di diffusione? Al fine di rispondere a tali domande, in questo lavoro utilizziamo i dati di una ricca survey somministrata alle imprese italiane sull'adozione delle nuove tecnologie digitali ed esaminiamo i loro modelli di adozione. Lo studio esplora quali siano le principali caratteristiche del tessuto produttivo italiano che si associano al cambiamento tecnologico nell'economia italiana, fornendo evidenza empirica utile al policymaker. I risultati delle analisi econometriche condotte a livello settore-regione indicano che le caratteristiche della governance aziendale, i modelli di innovazione e il tipo di relazioni industriali sono predittori significativi della disomogenea distribuzione regionale $e$ settoriale degli investimenti in Industria 4.0.

\section{Citation}

Cirillo V., Fanti L., Mina A., Ricci A. (2021), Upgrading Italy's Industrial Capacity: Industry 4.0 across Regions and Sectors, Sinappsi, XI, n.2, pp.14-35

\section{Keywords}

Industry 4.0

Technological innovation

Regions
Parole chiave

Industria 4.0

Innovazione tecnologica

Regioni

*Corresponding author: valeria.cirillo@uniba.it

Funding acknowledgments: Valeria Cirillo acknowledges the support of the Italian National Research Project - PRIN 2017 'Regional Policies, Institutions and Cohesion in the South of Italy' (Project code 2017-4BE543; website www.prin2017mezzogiorno.unirc.it), financed by the Italian Ministry of Education, University and Scientific Research from 2020 to 2023. Andrea Mina acknowledges the support of ARTES 4.0 Advanced Robotics and enabling digital TEchnologies \& Systems 4.0, Centro di Competenza ai sensi dell'art. 1, c. 115, L. 11/12/2016, n. 232 e del DD di Concessione della DGPICPMI Prot. 09/2019 del 29/4/2019, CUP: B81J18000090008 and GROWINPRO project on Growth Welfare Innovation Productivity that has received funding from the European Union Horizon 2020 research and innovation programme under grant agreement No. 822781. 


\section{Introduction}

After displaying a marked slowdown in output and productivity growth since the mid-1990s, Italy was one of the countries worst hit by the 2008 crisis. In the recovery process, it was lagging behind comparable Eurozone economies even before the damage caused by the pandemic. Net of well-known macroeconomic factors, specific challenges have contributed to this economic outlook, including a fragmented productive system characterised by a very high share of small firms, a pronounced focus on traditional sectors relative to high-tech sectors, and a weak - and weakening - propensity to invest. The implications for the innovation capacity of the economy are deep and far-reaching. First of all, expenditures on research and development activities, and corresponding patent yields, are low by international standards; secondly, riskaversion and the absence of specialist investors are associated with steep financial constraints and credit rationing for young firms with growth potential; and finally, underinvestment in human capital limits not only the development of innovation, but also the absorption of new scientific and technological knowledge (Bugamelli et al. 2012; Dosi et al. 2019; Bugamelli et al. 2020).

When we consider sources of productivity growth from which other economies derived longterm benefits, Italy was slow in adapting to the ICT revolution. Indeed, despite some indications of progress over the last few years, Italian firms have generally been less digitalised than their EU competitors according to both national (Istat 2017, 2018; MISE 2018) and international sources (European Commission 2018). Against this backdrop, and in the context of increased international competition, the new wave of enabling technologies that go under the Industry 4.0 paradigm is generating new competitive challenges as well as new opportunities for growth (Martinelli et al. $2021)^{1}$. Industry 4.0 results from the convergence of a number of correlated technologies, including advanced automation with high $\mathrm{Al}$ content and strong reliance on big data, internet of things, 3D printing and the cloud, which should constitute the backbone of the 'smart' factory of the future (Kagermann et al. 2013).

Given their potential, these technologies have attracted great interest among policy-makers and several incentive schemes have been introduced to foster their diffusion in an attempt to upgrade the productive infrastructure of national economies. Unsurprisingly, diffusion rates have been uneven across firms, and heavily dependent on adopters characteristics (Graetz and Michaels 2018; Gal et al. 2019; Cirillo et al. 2020a). The emergent firm-level evidence seems to indicate that the adoption of these new technologies generates positive performance outcomes (Acemoglu et al. 2020; Domini et al. 2021; Koch et al. 2021, Cirillo et al. 2021), thus validating the policy interest towards this particular group of technologies. Naturally, different economic contexts provide different opportunities for investment, and in a context as diverse as the Italian economy, it is essential to examine the regional and sectoral patterns of diffusion in order to gain insights into the drivers of structural change. To achieve this objective, we exploit rich firm survey data on the adoption of the new digital technologies and provide 1) detailed descriptive analyses of diffusion across regions and sectors and 2) new econometric evidence of the drivers of diffusion where the units of analysis are region-sector pairs.

\section{The diffusion of 14.0 investments: a descriptive overview}

The empirical analysis presented in the following Sections is based on the $V$ Rilevazione Imprese e Lavoro (RIL) survey conducted in 2018 on a representative sample of Italian companies operating in the non-agricultural private sector. The RIL survey collects a rich set of information about workforce composition, workplace characteristics, structure of industrial relations (trade union representation, supplementary agreements to the CCNL, etc.), productive specialization and other variables proxying firm strategies (such as the propensity to introduce product and process innovations). The $\mathrm{V}$ wave of the RIL-Inapp survey included a new set of questions specifically designed to collect information

1 For simplicity in this article we use the label 'Industry 4.0' techs, although 'Industry 4.0' is a political project implemented in Italy in analogy with 'Industrie 4.0 platform', 'Advance manufacturing platform' and 'Made In China 2025' in order to boost high-tech automation in the manufacturing of Germany, the United States and China respectively (see in this regard Pardi 2019). 


\section{Chart 1. Share of firms investing in 14.0 techs by regions and sectors}
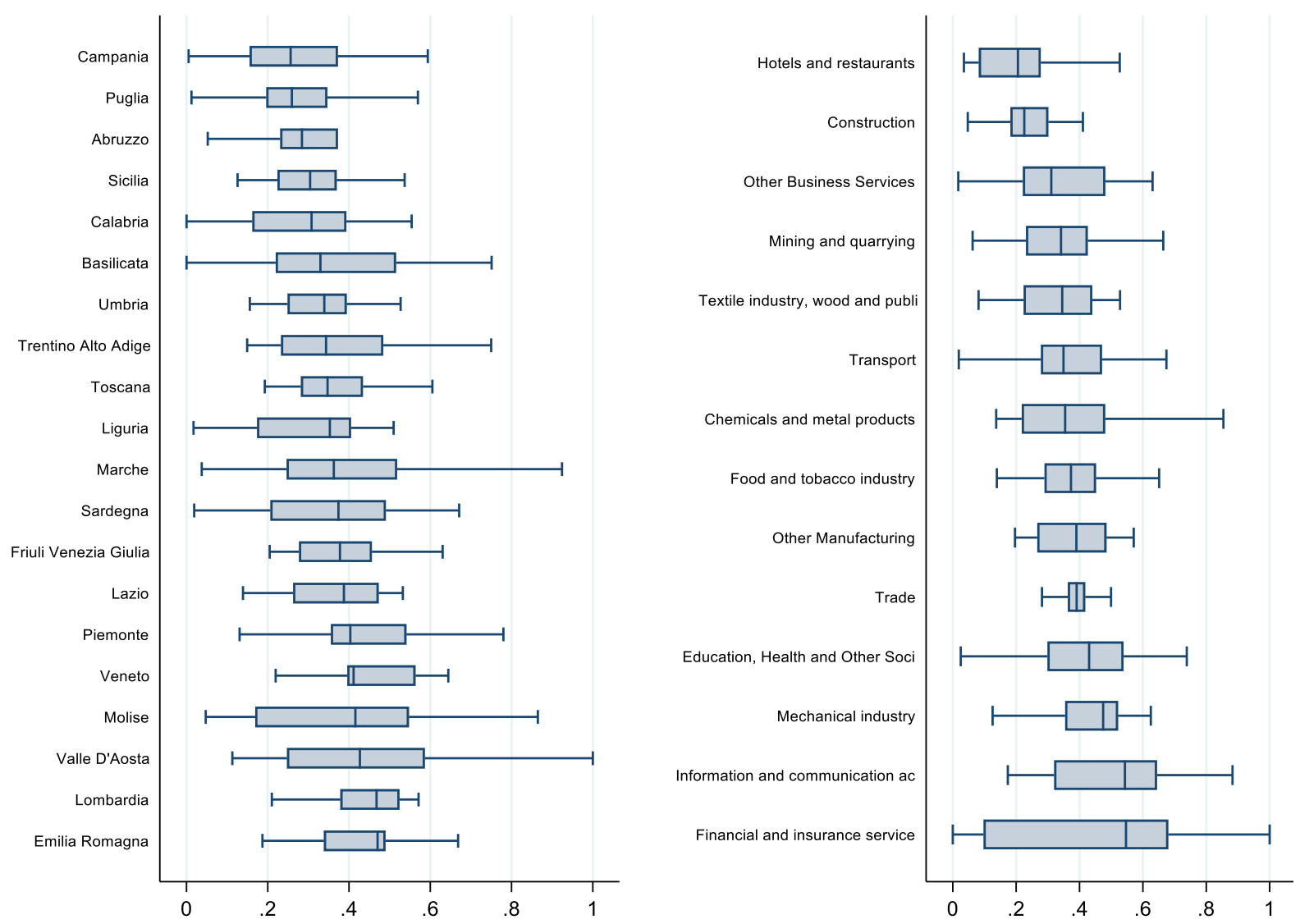

Note: the image above is a boxplot which is a standardized way of displaying the distribution of 14.0 adopters. It provides insights on the minimum, first quantile, median, third quantile and maximum of the share of firms adopting 14.0 techs for each region/sector.

Source: Authors' elaborations on RIL 2018 data

on the introduction of new digital technologies. In the section 'Innovation, Internationalization, Extension of markets', a specific question was added on investments in new technologies over the period 2015-2017: "In the period 2015-2017 did the firm invest in new technologies?". Respondents were presented with the following options: Internet of things (IoT), Robotics, Big data analytic, Augmented reality and Cybersecurity.

By relying on companies' replies to this new set of questions, in this Section we provide a brief descriptive overview of investments in 14.0 technologies discussing their distributions across Italian regions and economic sectors. The sectorregion unit of analysis allows us to evaluate the existence of patterns of dispersion/concentration of 14.0 investments in the Italian economy.

As discussed in Cirillo et al. (2020a), the 14.0 paradigm still has limited diffusion among Italian firms, with $26 \%$ of firms reporting the adoption of at least one of these new enabling technologies between 2015 and 2017. However, some geographical concentration patterns and sectoral heterogeneity can be clearly seen in relation to 14.0 adoption. As shown in Chart 1, the share of firms declaring an investment in 14.0 technologies between 2015 and 2017, is relatively higher in northern regions (Valle d'Aosta, Lombardy and Emilia Romagna) as compared to Centre and Southern ones. A similar ranking results from the 
Figure 1. Adoption rate in manufacturing (\%)

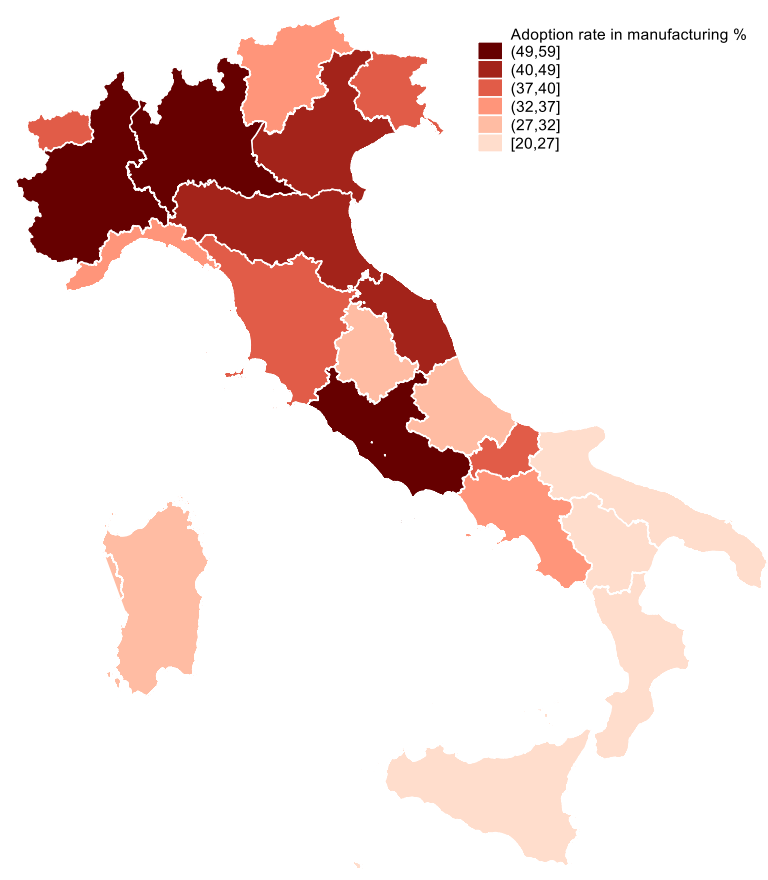

Source: Authors' elaborations on RIL 2018 data

regional disaggregation of the Digital Economy and Society Index provided by the European Commission².

Chart 1 also shows a prevalence of 14.0 investments in manufacturing sectors related to Mechanical activities, whereas Information and Communication, and Financial and Insurance are the service sectors with higher shares of firms investing in 14.0.

Moreover, Chart 1 indicates relatively higher dispersion of investments for specific regions (e.g., Valle d'Aosta, Marche, Molise and Basilicata) and sectors (e.g., Chemicals, Information and Communications, and Financial services) as compared to the others. This evidence suggests the coexistence of few innovative firms adopting new 14.0 technologies with a large
Figure 2. Adoption rate in service (\%)

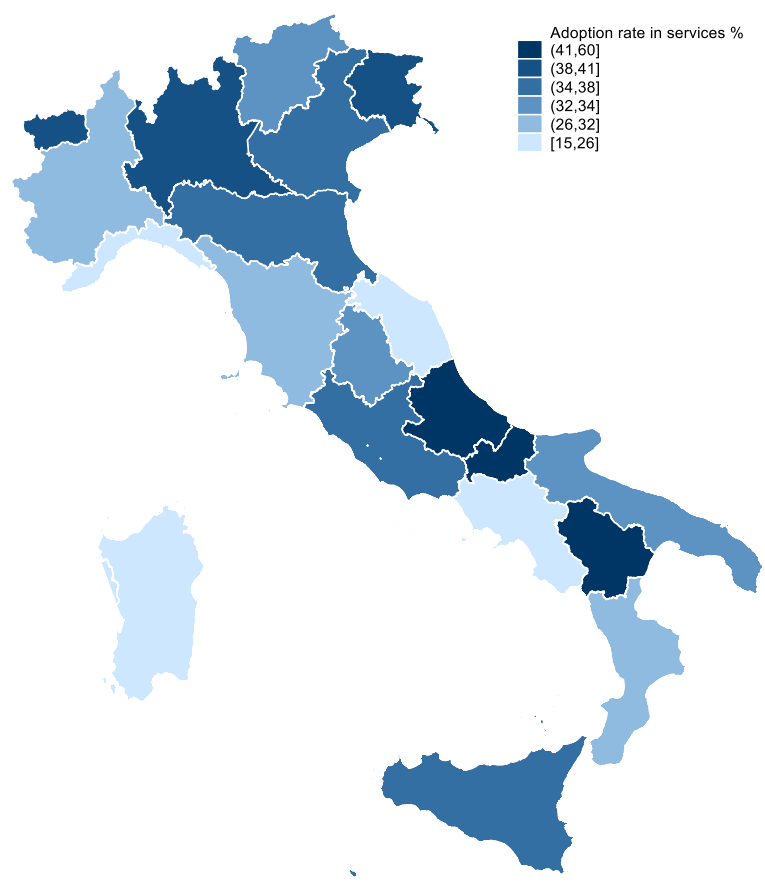

Source: Authors' elaborations on RIL 2018 data

population of non-adopters. Emilia Romagna and Lombardy are the Italian regions registering the highest median level of adoption rates, and the lowest dispersion rates, which suggest a rather uniform degree of adoption by firms located in those areas ${ }^{3}$. Similarly, we detect high dispersion in the adoption rates of 14.0 techs also at the sectoral level. This is consistent with the high degree of firms' heterogeneity characterizing the structure of the Italian economy at both geographical and sectoral levels (Bugamelli et al. 2012; Costa et al. 2020) and with the 'neo-dualism' that has been identified between few high-performing firms and a large group of low-performing laggard firms (Dosi et al. 2012, 2019).

By aggregating the adoption rate of 14.0

2 According to the regional disaggregation of the Digital Economy and Society Index (DESI 2020), in Italy the best performance is achieved by Lombardy, and the worst one by Calabria. Among the eleven regions scoring above the national average, eight regions are in the North (Lombardy, Emilia-Romagna, Friuli Venezia-Giulia, Veneto, Liguria, Piedmont and the autonomous provinces of Trento and Bolzano) and three are in the Centre (Lazio, Tuscany and Umbria). All the other regions are below the Italian average and located in the South. It is worth pointing out that the DESI index captures slightly different - although highly correlated - dimensions of digitization processes compared to 14.0 investments. In fact, DESI includes five domains related to connectivity, human capital, use of internet services, integration of digital technologies and digital public services, whereas our measure of 14.0 adoption refers to both digitization and automation type of techs.

3 This picture is highly consistent with the one in Bratta et al. (2020) on the entire population of Italian firms. Focusing on fiscal data and having access to information concerning the uptake of Industry 4.0 fiscal incentives, the authors found that the highest shares of investments benefitting from hyper depreciation are in Northern Italy, with Lombardy (33.2\%), Veneto (17.5\%) and Emilia Romagna (15.6\%) at the top of the ranking. 
Chart 2. Share of firms by number of 14.0 technologies adopted across sectors

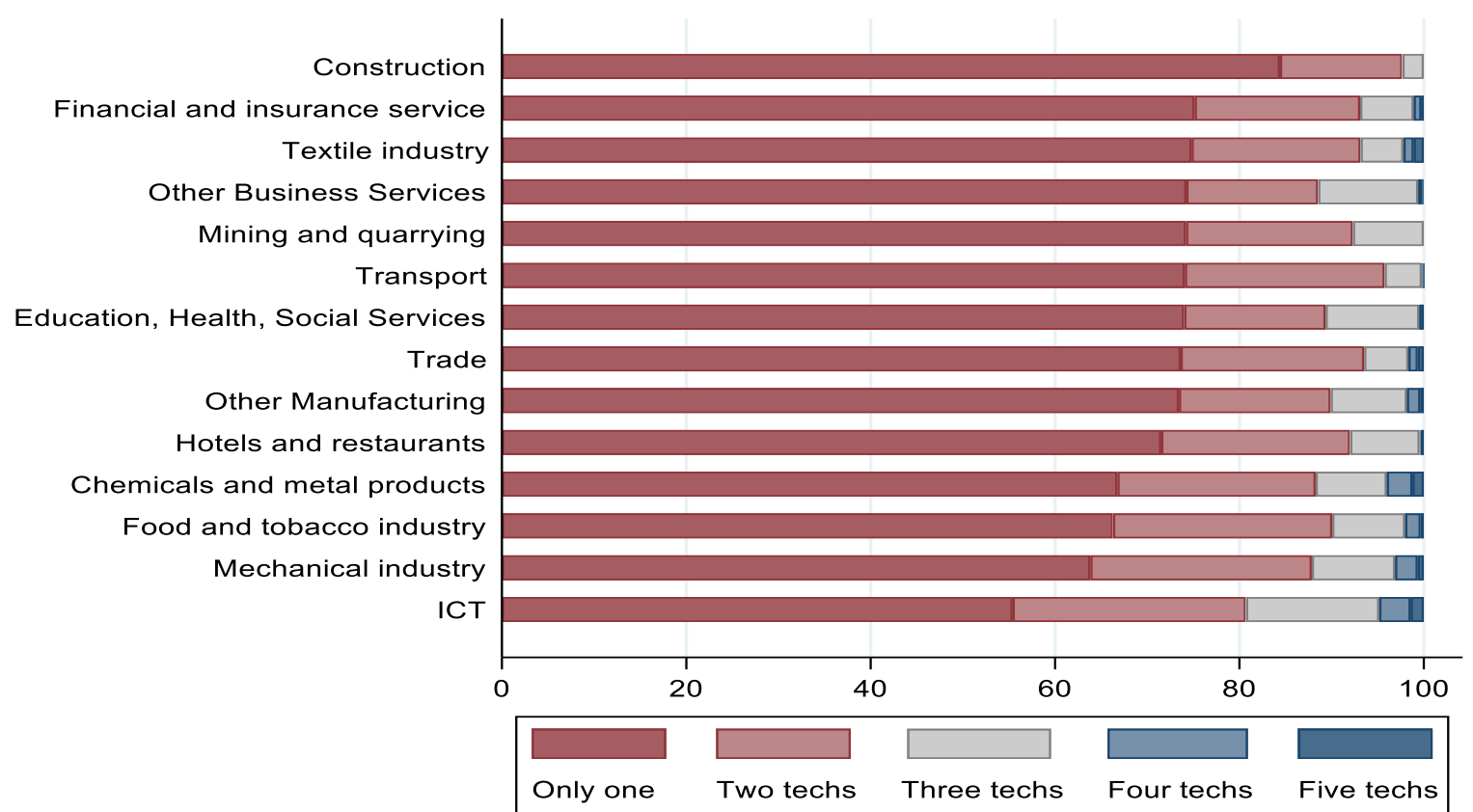

Source: Authors' elaborations on RIL 2018 data

technologies at a sectoral level in manufacturing (Figure 1) and service (Figure 2) sectors, we can more clearly illustrate the strong geographical heterogeneity between Northern and Southern areas of the country, and the way in which this reflects different patterns of sectoral specializations. As we can see, Piedmont, Lombardy (North-North West) and Lazio (Centre) are characterized by higher adoption rates in manufacturing sectors, followed by Veneto, Emilia Romagna (North East) and Marche (Centre), whereas higher adoption rates in service sectors are recorded in Abruzzo, Molise and Basilicata (South), followed by Valle D'Aosta, Lombardy (North-North West) and Friuli-Venezia Giulia (North East).
Charts 2 and 3 provide a clear indication of the prevalence of a single-technology, rather than a multi-technology, adoption strategy for Italian firms at both geographical and sectoral levels. Focusing on firms declaring to have invested in at least one 14.0 technology, we computed the number of 14.0 investments realized (from 1 to 5 technology types) and plot in Charts 2 and 3 the share of firms by the number of investments performed in new technologies across sectors and regions. Overall, those regions and sectors characterized by higher adoption rates (Figure 1 and 2) are also the same reporting, on average, a higher adoption of more than one type of technology. Indeed, Chemicals, Mechanics, Food and Tobacco, Information and

Table 1. Share of firms investing in 14.0 by type of tech and macro-region (\%)

\begin{tabular}{lcccccc}
\hline Macroregion & At least one tech & IOT & Robotics & Big Data Analytics & Augmented reality & Cyber security \\
\hline North West & 36.72 & 6.75 & 4.51 & 5.23 & 2.30 & 32.68 \\
\hline North East & 37.70 & 7.28 & 4.70 & 5.48 & 1.89 & 32.95 \\
\hline Center Italy & 35.90 & 7.96 & 4.19 & 6.67 & 3.37 & 29.77 \\
\hline Southern Italy & 24.52 & 4.80 & 1.64 & 3.06 & 1.00 & 21.15 \\
\hline Total & $\mathbf{3 3 . 6 2}$ & $\mathbf{6 . 6 2}$ & $\mathbf{3 . 7 4}$ & $\mathbf{5 . 0 3}$ & $\mathbf{2 . 0 9}$ & $\mathbf{2 9 . 1 5}$ \\
\hline
\end{tabular}

Note: percentages calculated on companies with at least 5 employees.

Source: Authors' elaborations on RIL 2018 data 
Chart 3. Share of firms by number of 14.0 technologies adopted across regions

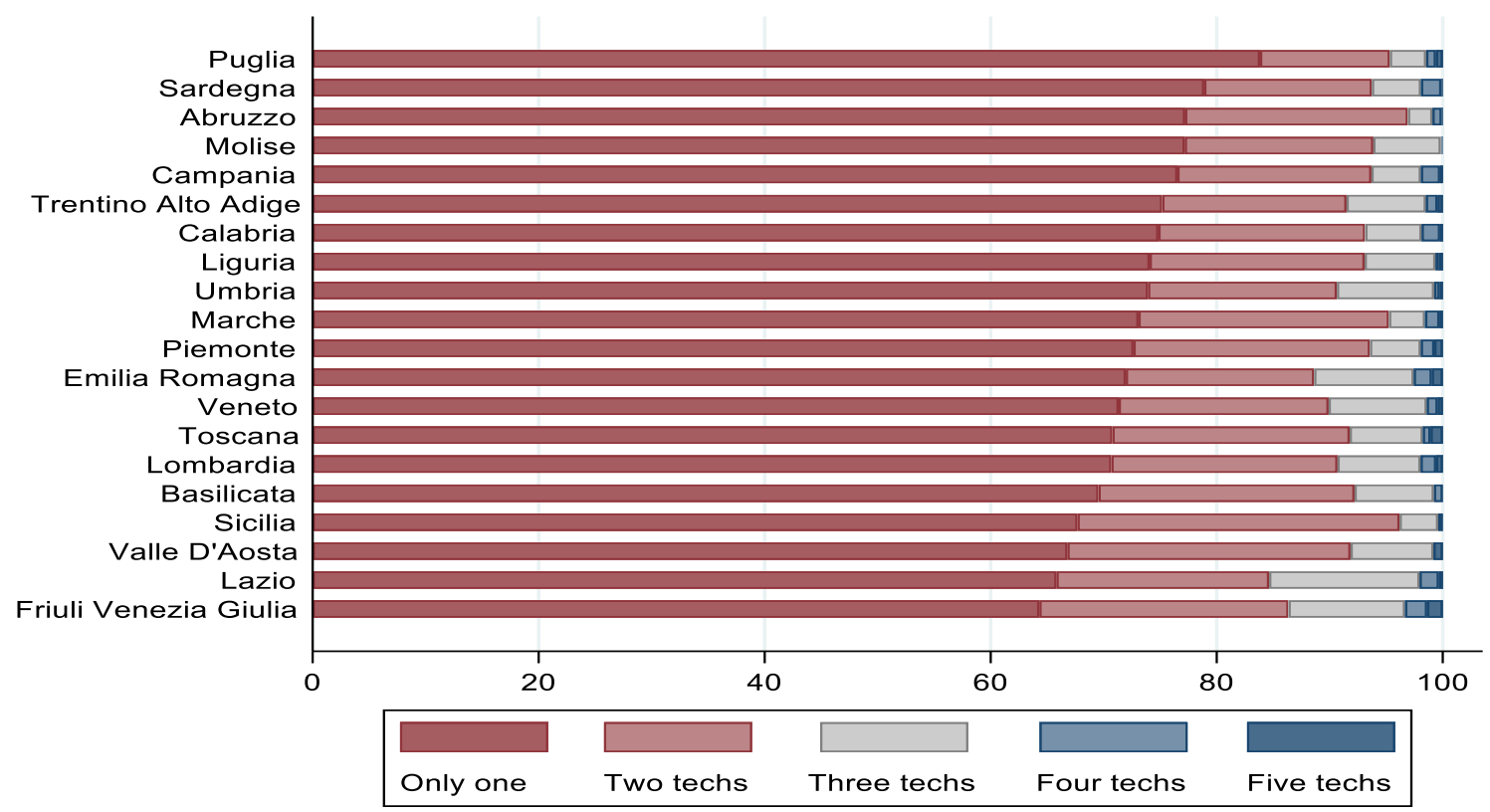

Source: Authors' elaborations on RIL 2018 data

Communication, and Financial services present a relatively higher share of firms pursuing a multitechnology adoption strategy, with prevalent firm location in Piedmont, Emilia Romagna, Lombardy, Friuli-Venezia Giulia, Veneto and Valle d'Aosta (North), Lazio, Marche and Tuscany (Centre), and Basilicata and Sicilia (South).

Table 1 distinguishes between firms investing in "at least one" 14.0 technology and firms adopting a specific type of technology, that is 'IoT', 'Robotics', 'Big Data Analytics', 'Augmented Reality' or 'Cybersecurity'. Data related to the adoption of at least one 14.0 confirm a certain degree of geographical heterogeneity among the Italian firms. Indeed, North West and North East macro-regions present higher shares of firms adopting at least one 14.0 technology, i.e. respectively the $36.72 \%$ and $37.70 \%$, as compared to Centre $(35.90 \%)$ and Southern areas (24.52\%). Among the different types of 14.0 technologies, Cybersecurity is the most frequently adopted. Indeed, $29.15 \%$ of total firms investing in 14.0 reported adopting this type of technology, among which $32.68 \%$ and $32.95 \%$ are located, respectively, in the North West and
North East against the $29.77 \%$ and $21.15 \%$ located respectively in Centre and Southern macro-regions. This is in line with results presented in Cirillo et al. (2020a) about the prevalence of investments and adoption in Cybersecurity rather than in standard production technologies that would pave the way for a radical digital transformation.

Charts 4 and 5 provide insights about the diffusion of specific 14.0 incentives related to the Piano Nazionale Industria 4.0 policy scheme (see footnote 11) among Italian companies across, respectively, regions and sectors ${ }^{4}$.

In charts 4 and 5 the incidence of 14.0 incentives is computed on two different populations of firms: (i) firms making any investment in 2017 (i.e. any type of investment, including, but not limited, to 14.0); (ii) firms introducing at least one 14.0 technology (IoT, Cybersecurity, Augmented Reality, Big Data Analytics, or Robotics), over the 20152017 period, and which also made any investment in 2017. Therefore, the light red bar in both graphs represents a subpopulation of the light blue bar. To some extent the light red bar proxies the share of early adopters accessing 14.0 incentives in 2017.

4 In RIL 2018 there is a specific question on incentives (including those of the National Plan of 14.0) which is addressed exclusively to those firms that have invested in 2017. 


\section{Chart 4. Share of firms benefiting from 14.0 subsidies by regions*}

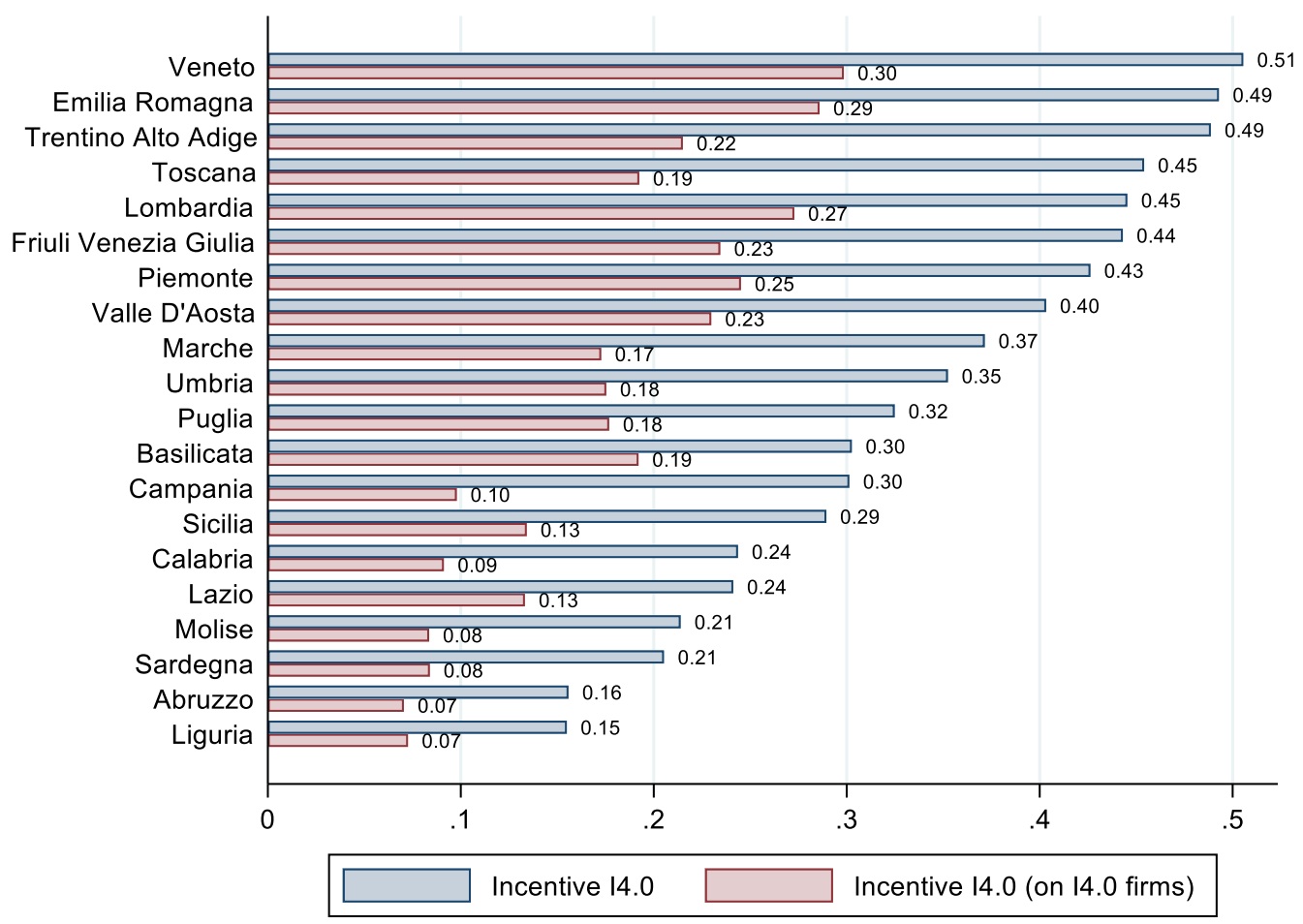

* Since the question is exclusively addressed to firms that have declared to realize general investments in 2017, we compute the incidence of 14.0 incentives (incentives related to the Plan 14.0) on two subpopulations: (i) firms realizing general investments; (ii) firms introducing at least one 14.0 techs - loT, Cybersecurity, Augmented Reality, Big Data Analytics, Robotics.

Source: Authors' elaborations on RIL 2018 data

A relatively larger role is played by 14.0 incentives in those regions (Chart 4) and sectors (Chart 5) where, on average, higher 14.0 adoption rates are reported between 2015 and 2017. This may highlight how the 14.0 policy incentive scheme, which is a 'neutral' measure potentially accessible by all firms investing in 14.0 technologies, may have not redressed pre-existing gaps in the distribution of technological capabilities among Italian regions and sectors, and more specifically between Northern and Southern areas, and between high and mediumlow tech sectors.

Has the 14.0 policy incentive scheme affected the behavior of firms leading them to introduce new enabling techs? Although a pure evaluation exercise is not feasible due to the lack of a proper control group since the hyper-depreciation policy (and most of 14.0 measures) was a universal policy, which targeted all private companies; in what follows we exploit a specific question that has been introduced in the RIL 2018 survey. Investing firms that have received incentives were asked if in absence of such incentives would have: (i) made the investment anyway, for the same amount; (ii) made the investment anyway, for a smaller amount; (iii) not have made the investment.

Table 2 and Table 3 show the distribution of firms by behavioral choices and, respectively, regions and sectors. The latter have been ordered according to the highest share of companies in the region/sector declaring that in absence of incentives would have realized the investment anyway for the same amount ${ }^{5}$.

As expected, a large proportion of firms having introduced 14.0 techs, accessing to the fiscal incentive scheme and declaring that would have made the investment even in the absence of fiscal incentive are located in Northern regions: Lombardy, Veneto, Piedmont and knowledge-intensive service

5 Tables 2 and 3 can be directly linked with evidence in Charts 4 and 5 (light red bars) referring to the same population of firms. 


\section{Chart 5. Share of firms benefiting from 14.0 subsidies by sectors}

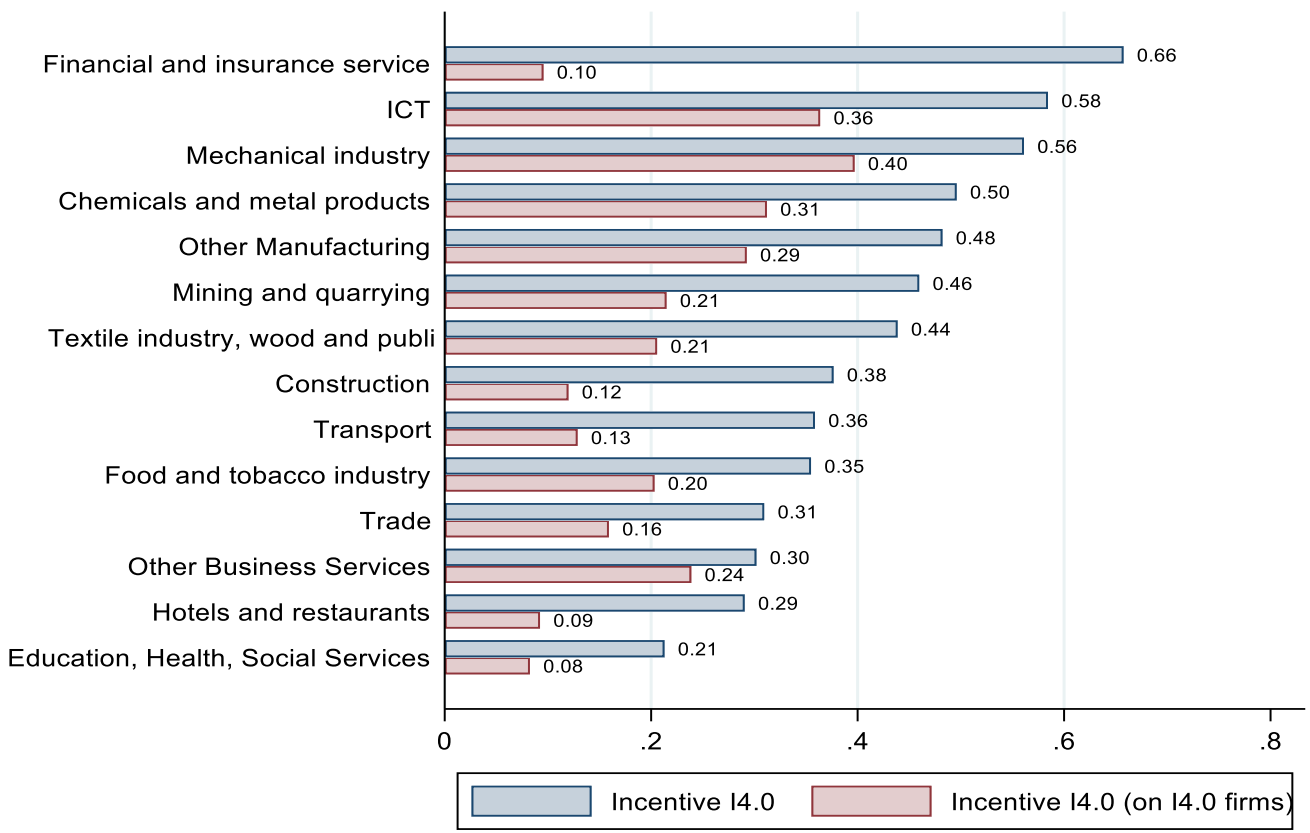

Source: Authors' elaborations on RIL 2018 data

Table 2. Distribution of firms by investment choices in absence of 14.0 incentive and regions (\%)

\begin{tabular}{|c|c|c|c|}
\hline Regions & $\begin{array}{c}\text { made the investment } \\
\text { anyway, for the same } \\
\text { amount }\end{array}$ & $\begin{array}{c}\text { made the investment } \\
\text { anyway, for a smaller } \\
\text { amount }\end{array}$ & $\begin{array}{l}\text { not have made the } \\
\text { investment }\end{array}$ \\
\hline Lombardia & 64.03 & 23.98 & 11.99 \\
\hline Veneto & 59.88 & 30.43 & 9.69 \\
\hline Umbria & 59.28 & 32.99 & 7.72 \\
\hline Piemonte & 57.66 & 31.99 & 10.35 \\
\hline Abruzzo & 56.21 & 39.62 & 4.17 \\
\hline Emilia-Romagna & 55.42 & 33.23 & 11.35 \\
\hline Toscana & 55.19 & 25.87 & 18.94 \\
\hline Friuli-Venezia Giulia & 54.46 & 33.49 & 12.05 \\
\hline Campania & 52.33 & 37.7 & 9.97 \\
\hline Lazio & 52.07 & 36.04 & 11.89 \\
\hline Trentino-Alto Adige & 51.58 & 29.95 & 18.47 \\
\hline Puglia & 51.17 & 26.24 & 22.59 \\
\hline Marche & 50.21 & 41.62 & 8.17 \\
\hline Sardegna & 48.64 & 36.85 & 14.51 \\
\hline Valle D'Aosta* & 48.38 & 37.64 & 13.98 \\
\hline Liguria & 48.21 & 40.86 & 10.93 \\
\hline Molise* & 46.73 & 37.14 & 16.13 \\
\hline Calabria* & 41.15 & 37.22 & 21.63 \\
\hline Basilicata* & 37.24 & 50.35 & 12.4 \\
\hline Sicilia & 35.11 & 42.52 & 22.37 \\
\hline Total & 57.4 & 30.31 & 12.3 \\
\hline
\end{tabular}

*Low reliability due to low number of observations.

Source: Authors' elaborations on RIL 2018 data 
Table 3. Distribution of firms by investment choices in absence of 14.0 incentive and sectors (\%)

\begin{tabular}{|c|c|c|c|}
\hline Sectors & $\begin{array}{c}\text { made the investment } \\
\text { anyway, for the same } \\
\text { amount }\end{array}$ & $\begin{array}{c}\text { made the investment } \\
\text { anyway, for a smaller } \\
\text { amount }\end{array}$ & $\begin{array}{l}\text { not have made the } \\
\text { investment }\end{array}$ \\
\hline Financial and insurance* & 85.56 & 13.24 & 1.2 \\
\hline Other Business Services & 80.21 & 12.9 & 6.89 \\
\hline $\mathrm{ICT}$ & 73.58 & 21.05 & 5.37 \\
\hline Mining and quarrying* & 73.33 & 21.04 & 5.63 \\
\hline Transport & 66.32 & 23.99 & 9.69 \\
\hline Food and tobacco & 60.69 & 28.28 & 11.03 \\
\hline Trade & 56.91 & 26.07 & 17.03 \\
\hline Education. Health & 55.78 & 38.57 & 5.65 \\
\hline Construction & 51.1 & 38.75 & 10.15 \\
\hline Mechanical industry & 49.45 & 37.44 & 13.1 \\
\hline Other Manufacturing & 48.57 & 36.07 & 15.36 \\
\hline Hotels and restaurant & 46.23 & 45.44 & 8.32 \\
\hline Chemicals and metal products & 44.3 & 40.13 & 15.56 \\
\hline Textile industry, wood & 43.59 & 34.9 & 21.51 \\
\hline Total & 57.4 & 30.31 & 12.3 \\
\hline $\begin{array}{l}\text { *Low reliability due to low number } \\
\text { Source: Authors' elaborations on RIL }\end{array}$ & $\begin{array}{l}\text { vations. } \\
\text { ata }\end{array}$ & & \\
\hline
\end{tabular}

sectors (ICT, Financial and insurance activities, etc.).

Among those regions where the incentive policy scheme seems to have affected investment choices of firms: Puglia and Sicily and manufacturing - both high-tech (chemicals and metal products) and lowtech industries (textiles). However, we do not know if these firms using fiscal incentives had never invested in 4.0 technologies before ${ }^{6}$.

All in all, pure descriptive evidence seems to suggest that: (i) the uptake of incentive schemes have reached firms located in those regions and sectors having already experienced a path toward digitalization; (ii) these companies in most of cases would have realized the 14.0 investment anyway; (iii) there is a non-negligible share of companies located in Central and Southern regions that in absence of incentives would not have realized the investment ${ }^{7}$. This picture is in line with results in Bratta et al. (2020) on fiscal data showing that firms investing in subsidized 4.0 technologies in 2017, besides being more profitable, more productive and less dependent on external funds to finance their activities, were also more prone than the average Italian company to invest and take advantage from the related fiscal incentives (Bratta et al. 2020, p.15).

\section{Exploring regional and sectoral determinants of 14.0 investments}

In light of the descriptive evidence we have discussed, in this Section we take a step forward in the analysis. More in detail, we explore which factors are more likely associated with the concentration of 14.0 investments. These factors can be related to the local productive structure and to the agglomeration of firms with specific features in terms of corporate governance, quality and types of industrial relations, degree of internationalization and innovativeness.

We estimated two different regressions having

6 According to the Ministry of Finance data on the uptake of fiscal incentives matched with the ICT survey run by the Italian National Statistical Office, around $85 \%$ of firms that benefitted from hyper-depreciation in 2017 had never invested in advanced digital technologies before.

7 Due to the construction of the questionnaire, we are not able to perfectly match investments in 14.0 with the incentive plan since the question on 14.0 investments refers to 2015-2017 while the question on incentives on 14.0 to 2017 . Furthermore, incentives of the Industry 4.0 Plan include a wide range of measures such as R\&D tax credit, tax depreciation allowances known as super-depreciation which is less generous than hyper-depreciation and not targeting exclusively investments in advanced digital technology but basically all kinds of new machinery and equipment (Bratta et al. 2020). 
as dependent variables, respectively: (i) the share of firms investing in at least one 14.0 tech in each Italian sector-region pair; (ii) the average number of 14.0 techs adopted in each Italian sector-region pair. The estimates have been computed by applying standard Ordinary Least Squares (OLS) and robust standard errors. In order to assess which factors are more likely associated with the geographical distribution of 14.0 investments, we introduce as explanatory variables a broad set of covariates that can be grouped into three main set of firm/territorial characteristics: (i) corporate governance profiles (share of firms in the sector-region pair with managers having a degree and high-school diploma with respect to share of firms whose management has elementary or lower-level education; share of firms with familyownership management); (ii) prevailing type of industrial relations in the sector-region (share of firms having a local trade union representative - RSA and $\mathrm{RSU}^{8}$; share of firms in the sector-region that have signed opt-out clauses with respect to national or sectoral collective agreements ${ }^{9}$ ); (iii) degree of internationalization of firms for each sector-region pair (share of exporting firms; share of firms signing agreements with foreign companies; share of firms outsourcing production abroad); (iv) input and output of innovation at the sector-region level (share of firms investing in R\&D; share of firms introducing product and process innovations; share of firms with public procurement contracts). In addition to the aforementioned drivers, we also include a set of controls proxing industrial structure of the sectorregion such as average value-added per employee and average size of firms. Finally, we include the average number of trained employees in the sectorregion over total employment as a proxy for the availability of a qualified and trained workforce at the sectoral/regional level.

Tables 4 and 5 illustrate the correlations between the incidence of firms' investment in at least one 14.0 technology (i.e., our dependent variable) and a set of variables indicating the shares of firms with different characteristics populating each Italian sector in a specific region (i.e., the unit of analysis is given by the intersection of fourteen economic sectors in twenty regions). Moreover, we include among controls a set of region dummy variables for regions in Table 4 and for sectors in Table 5, allowing us to detect inter-regional variability (Table 4) among covariates in affecting the geographical concentration of 14.0 investments, and inter-sectoral variability (Table 5) among the same set of covariates with respect to our dependent variable ${ }^{10}$.

The four columns in Table 4 show the results of four models that differ from one another because of the stepwise inclusion of a variable capturing the share of firms that received a general government subsidy (column 2), a 14.0 subsidy (column 3), a specific 14.0 subsidy named 'Super Ammortamento' ${ }^{11}$.

Among the main factors associated with the share of 14.0 investments across sectors and regions (Table 4) both corporate governance features and innovative behavior play a major role. More in detail, the share of family-controlled firms is significantly and negatively correlated with the incidence of

8 RSA and RSU are two trade union representation bodies for employees, both public and private. RSUs - Rappresentanza Sindacale Unitaria - are elected by all workers present in the company, regardless of their membership of a trade union. In contrast, RSAs - Rappresentanza Sindacale Aziendale - are elected by members of a specific trade union. Thus, RSUs have the general representation of workers and participate in company bargaining, whereas RSAs protect only trade union members and until a few years ago do not participate in company bargaining (Keune 2011).

9 Opening clauses (opt-out clauses) are derogation clauses giving firms the chance to deviate from norms set under intersectoral or sectoral agreements, including minimum wages, when firms suffer from temporary economic hardship.

10 The inclusion of sectoral dummies allows to compare different sectors (i.e., manufacturing in Veneto vs. construction in Veneto, etc.), whereas the inclusion of regional dummies sheds lights on between regions heterogeneities (i.e., manufacturing in Veneto vs. manufacturing in Puglia).

11 The set of 14.0 incentives includes: i) 'Super Ammortamento' (a 140\% fiscal bonus over the depreciation charges for investments in new capital goods purchased or leased over October 2015- December 2017); ii) 'Iper Ammortamento' (that is a $250 \%$ fiscal bonus over the depreciation charges for investments in new tangible assets, devices and technologies enabling the 4.0 transformation over December 2017- June 2018); iii) the contribution provided by Ministry of Economic Development for interest payments on bank loans requested to invest in equipment, machinery or capital-goods related to production and digital technologies implementation (so-called Nuova Sabatini); iv) the patent box; v) $50 \%$ tax credit on incremental expenses in R\&D; vi) Start-up and PMI measures for small innovative companies. These measures are part of a more general plan designed by the Italian Ministry in 2016 and subsequently relaunched under the name of Piano Nazionale Industria 4.0, https://bit.ly/3068e2J 
14.0 investments, indicating a weaker technological dynamic of those sectors/regions characterized by a relevant presence of family-controlled companies.

Conversely, innovative activities are among the strong predictors of 14.0 investments. That is, even controlling for regional specific features that can influence the share of investments in 14.0, the presence of firms persistently investing in R\&D and having introduced in the last three years product innovations is positively associated with the share of 14.0 adopters. This confirms, on the one hand, the positive role of stronger innovative efforts on the adoption of new enabling technologies and, on the other hand, the path dependency of technological trajectories of sectors following over time the development of specific technologies.

Industry 4.0 technologies have the potential to reconfigure production processes on a global scale, enabling coordination and synchronization among suppliers in fragmented and geographically dispersed production chains (Garibaldo 2017; Freddi et al. 2018; Gaddi et al. 2020). However, the degree of internationalization of the sectorregion is not associated with the distribution of 14.0 investments. More specifically, neither the share of firms exporting (positively) nor the degree of outsourcing (negatively) are related with the adoption of new technologies. While a negative association emerges between the share of companies signing commercial agreements with international companies and the diffusion of 14.0 investments, we cannot speculate further on this result because we do not have detail information on the specific typology of agreements.

Table 4 also shows that industrial relation features do not appear to be a significant driver of 14.0 investments at the sectoral-regional level, arguably because of the specificities of each industry with respect to the industrial relation framework applied to regulate the workforcemanagement interface.

Conversely, the share of trained workers over total employment level is positively associated to the share of 14.0 adopters, suggesting the existence of positive externalities between the availability of a trained workforce at the sectoral/regional level and the propensity of firms to be engaged in new enabling technologies.

Significance level and signs do not change when we include a control for the share of firms receiving some forms of incentives (columns 2, 3, 4). The 'Super Ammortamento' scheme - that is the more coherent in terms of timing of incentive (October 2015 - December 2017) with respect to the introduction of 14.0 techs (2015-2017) although not targeting exclusively investments in advanced digital technology but basically all kinds of new machinery and equipment - is significantly related with our dependent variable, meaning that sectors/regions registering higher share of firms having access to 'Super Ammortamento' are also those showing a higher share of 14.0 firms.

Table 5 mainly confirms the relationships detected in Table 4. However, the inclusion of sectoral dummies gives us the opportunity to control for sectoral specific factors affecting the share of 14.0 firms. Corporate governance features and innovation patterns of sectors are significant predictors of geographical/ sectoral distributions of 14.0 investments. Moreover, industrial relations turn out as a further significant element affecting the share of 14.0 adopters. In fact, the share of firms with trade union representation bodies - RSA - proxying the strength of specific trade union at the company level, is positively associated with 14.0 investments. This pattern supports previous evidence on the strategic role that trade union within the enterprise may have in the process of implementing new technologies by defining suitable organisational practices (Russo et al. 2019; Cirillo et al. 2020b) and contributing to create a collaborative environment between management and workforce.

Table 5 also highlights a negative relationship between the share of firms outsourcing productions abroad and 14.0 investments. Firms outsourcing productions are more likely to pursue cost competitiveness strategies than technological competitiveness (Vivarelli 1995; Vivarelli and Pianta 2000). Therefore, when comparing sectors across regions, we detect that those sector-region pairs characterized by higher proportions of outsourcing companies register on average a lower share of 14.0 adopters.

Finally, as in Table 4, the inclusion of variables proxying the share of companies benefiting from government incentives does not change magnitude nor sign of the coefficients. The proportion of companies receiving 'Super Ammortamento' incentives is still positively related to the share of 14.0 investments at the sectoral-regional level even when we control for sectoral specific features. 
Table 4. OLS estimates of a linear regression equation. Dependent variable: share of firms investing in at least one 14.0 technology (I)

\begin{tabular}{|c|c|c|c|c|}
\hline & (1) & $(2)$ & (3) & (4) \\
\hline & $\mathrm{b} / \mathrm{se}$ & $\mathrm{b} / \mathrm{se}$ & $\mathrm{b} / \mathrm{se}$ & $\mathrm{b} / \mathrm{se}$ \\
\hline \multirow[t]{2}{*}{ Share of firms with graduate management } & 0.092 & 0.089 & 0.085 & 0.096 \\
\hline & $(0.093)$ & $(0.091)$ & $(0.091)$ & $(0.091)$ \\
\hline \multirow[t]{2}{*}{ Share of firms with high-school management } & 0.114 & 0.104 & 0.104 & 0.110 \\
\hline & $(0.084)$ & $(0.082)$ & $(0.083)$ & $(0.080)$ \\
\hline \multirow[t]{2}{*}{ Share of family firms } & $-0.295 * *$ & $-0.296 * *$ & $-0.297^{* *}$ & $-0.288^{* *}$ \\
\hline & $(0.120)$ & $(0.120)$ & $(0.120)$ & $(0.121)$ \\
\hline \multirow[t]{2}{*}{ Share of firms with RSA (union representatives) } & 0.171 & 0.159 & 0.160 & 0.158 \\
\hline & $(0.130)$ & $(0.126)$ & $(0.127)$ & $(0.128)$ \\
\hline \multirow[t]{2}{*}{ Share of firms with RSU (union representatives) } & -0.148 & -0.160 & -0.153 & -0.144 \\
\hline & $(0.177)$ & $(0.181)$ & $(0.181)$ & $(0.178)$ \\
\hline \multirow[t]{2}{*}{ Share of firms signing opting out clauses } & -0.099 & -0.163 & -0.154 & -0.168 \\
\hline & $(0.206)$ & $(0.199)$ & $(0.204)$ & $(0.182)$ \\
\hline \multirow[t]{2}{*}{ Share of trained employees (log) } & $0.080 * * *$ & $0.081 * * *$ & $0.081^{* * *}$ & $0.075^{* * *}$ \\
\hline & $(0.026)$ & $(0.026)$ & $(0.026)$ & $(0.026)$ \\
\hline \multirow[t]{2}{*}{ Share of firms exporting } & -0.047 & -0.056 & -0.054 & -0.072 \\
\hline & $(0.071)$ & $(0.070)$ & $(0.070)$ & $(0.070)$ \\
\hline \multirow[t]{2}{*}{$\begin{array}{l}\text { Share of firms signing commercial agreements with } \\
\text { foreign companies }\end{array}$} & $-0.275^{*}$ & $-0.281 * *$ & $-0.277^{*}$ & -0.229 \\
\hline & $(0.144)$ & $(0.141)$ & $(0.142)$ & $(0.142)$ \\
\hline \multirow[t]{2}{*}{ Share of firms performing outsourcing } & -0.386 & -0.487 & -0.465 & -0.570 \\
\hline & $(0.580)$ & $(0.566)$ & $(0.573)$ & $(0.590)$ \\
\hline \multirow[t]{2}{*}{ Share of firms investing in R\&D } & $0.196 * * *$ & $0.197 * * *$ & $0.196^{* * *}$ & $0.198^{* * *}$ \\
\hline & $(0.059)$ & $(0.059)$ & $(0.059)$ & $(0.060)$ \\
\hline \multirow[t]{2}{*}{ Share of firms introducing process innovations } & 0.149 & 0.145 & 0.144 & 0.148 \\
\hline & $(0.103)$ & $(0.104)$ & $(0.105)$ & $(0.102)$ \\
\hline \multirow[t]{2}{*}{ Share of firms introducing product innovations } & $0.336 * * *$ & $0.325 * * *$ & $0.331 * * *$ & $0.337^{* * *}$ \\
\hline & $(0.107)$ & $(0.109)$ & $(0.108)$ & $(0.106)$ \\
\hline \multirow[t]{2}{*}{ Share of firms accessing to public procurement } & 0.060 & 0.054 & 0.055 & 0.058 \\
\hline & $(0.057)$ & $(0.057)$ & $(0.057)$ & $(0.058)$ \\
\hline \multirow[t]{2}{*}{ Share of firms receiving incentives } & & 0.126 & & \\
\hline & & $(0.112)$ & & \\
\hline \multirow[t]{2}{*}{ Share of firms receiving 14.0 incentives } & & & 0.101 & \\
\hline & & & $(0.116)$ & \\
\hline \multirow[t]{2}{*}{ Share of firms using 'Super Ammortamento' plan } & & & & $0.249 *$ \\
\hline & & & & $(0.146)$ \\
\hline Regional dummies & YES & YES & YES & YES \\
\hline \multirow[t]{2}{*}{ Constant } & 0.245 & 0.272 & 0.265 & 0.256 \\
\hline & $(0.175)$ & $(0.170)$ & $(0.171)$ & $(0.171)$ \\
\hline Number of observations & 280 & 280 & 280 & 280 \\
\hline Adj. R-Square & 0.438 & 0.442 & 0.439 & 0.449 \\
\hline
\end{tabular}

Notes: controls include average firm size, average firm value added and share of firms hiring employees; clustered standard errors in parentheses:

${ }^{*}$ statistical significance at $10 \%,{ }^{* *}$ at $5 \%,{ }^{* * *}$ at $1 \%$.

Source: Authors' elaboration on RIL 2018 data 
Table 5. OLS estimate of a linear regression equation. Dependent variable: share of firms investing in at least one 14.0 technology (II)

\begin{tabular}{|c|c|c|c|c|}
\hline & $(1)$ & $(2)$ & (3) & (4) \\
\hline & $\mathrm{b} / \mathrm{se}$ & $\mathrm{b} / \mathrm{se}$ & $\mathrm{b} / \mathrm{se}$ & $\mathrm{b} / \mathrm{se}$ \\
\hline \multirow[t]{2}{*}{ Share of firms with graduate management } & -0.067 & -0.068 & -0.069 & -0.053 \\
\hline & $(0.100)$ & $(0.099)$ & $(0.099)$ & $(0.098)$ \\
\hline \multirow[t]{2}{*}{ Share of firms with high-school management } & -0.065 & -0.068 & -0.071 & -0.057 \\
\hline & $(0.076)$ & $(0.075)$ & $(0.076)$ & $(0.075)$ \\
\hline \multirow[t]{2}{*}{ Share of family firms } & $-0.329 * * *$ & $-0.336 * * *$ & $-0.328 * * *$ & $-0.306 * * *$ \\
\hline & $(0.107)$ & $(0.108)$ & $(0.108)$ & $(0.108)$ \\
\hline \multirow[t]{2}{*}{ Share of firms with RSA (union representatives) } & $0.257^{*}$ & $0.245^{*}$ & $0.246 *$ & $0.249 *$ \\
\hline & $(0.145)$ & $(0.142)$ & $(0.143)$ & $(0.145)$ \\
\hline \multirow[t]{2}{*}{ Share of firms with RSU (union representatives) } & 0.133 & 0.141 & 0.150 & 0.171 \\
\hline & $(0.168)$ & $(0.170)$ & $(0.171)$ & $(0.168)$ \\
\hline \multirow[t]{2}{*}{ Share of firms signing opting out clauses } & -0.202 & -0.320 & -0.327 & -0.333 \\
\hline & $(0.228)$ & $(0.228)$ & $(0.231)$ & $(0.206)$ \\
\hline \multirow[t]{2}{*}{ Share of trained employees (log) } & $0.086 * * *$ & $0.082 * * *$ & $0.082 * * *$ & $0.071 * * *$ \\
\hline & $(0.024)$ & $(0.024)$ & $(0.024)$ & $(0.023)$ \\
\hline \multirow[t]{2}{*}{ Share of firms exporting } & -0.113 & -0.123 & -0.124 & $-0.144^{*}$ \\
\hline & $(0.075)$ & $(0.076)$ & $(0.075)$ & $(0.075)$ \\
\hline \multirow[t]{2}{*}{ Share of firms signing agreements with foreign companies } & -0.212 & -0.211 & -0.211 & -0.155 \\
\hline & $(0.130)$ & $(0.131)$ & $(0.131)$ & $(0.121)$ \\
\hline \multirow[t]{2}{*}{ Share of firms performing outsourcing } & -0.830 & $-0.988^{*}$ & $-0.957 *$ & $-1.014^{*}$ \\
\hline & $(0.574)$ & $(0.569)$ & $(0.563)$ & $(0.600)$ \\
\hline \multirow[t]{2}{*}{ Share of firms investing in R\&D } & 0.092 & 0.101 & 0.099 & 0.098 \\
\hline & $(0.067)$ & $(0.066)$ & $(0.066)$ & $(0.064)$ \\
\hline \multirow[t]{2}{*}{ Share of firms introducing process innovations } & 0.130 & 0.124 & 0.122 & 0.129 \\
\hline & $(0.123)$ & $(0.124)$ & $(0.125)$ & $(0.123)$ \\
\hline \multirow[t]{2}{*}{ Share of firms introducing product innovations } & $0.307 * * *$ & $0.299 * * *$ & $0.304 * * *$ & $0.318^{* * *}$ \\
\hline & $(0.113)$ & $(0.115)$ & $(0.113)$ & $(0.112)$ \\
\hline \multirow[t]{2}{*}{ Share of firms accessing to public procurement } & 0.098 & 0.097 & 0.103 & 0.096 \\
\hline & $(0.071)$ & $(0.072)$ & $(0.072)$ & $(0.071)$ \\
\hline \multirow[t]{2}{*}{ Share of firms receiving incentives } & & 0.163 & & \\
\hline & & $(0.104)$ & & \\
\hline \multirow[t]{2}{*}{ Share of firms receiving 14.0 incentives } & & & 0.164 & \\
\hline & & & $(0.113)$ & \\
\hline \multirow[t]{2}{*}{ Share of firms using 'Super Ammortamento' plan } & & & & $0.306^{* *}$ \\
\hline & & & & $(0.126)$ \\
\hline Sectoral dummies & YES & YES & YES & YES \\
\hline \multirow[t]{2}{*}{ Constant } & $0.441^{* * *}$ & $0.463 * * *$ & $0.451^{* * *}$ & $0.415^{* *}$ \\
\hline & $(0.164)$ & $(0.163)$ & $(0.163)$ & $(0.161)$ \\
\hline Number of observations & 280 & 280 & 280 & 280 \\
\hline Adj. R-Square & 0.432 & 0.440 & 0.439 & 0.451 \\
\hline
\end{tabular}

Notes: controls include average firm size, average firm value added and share of firms hiring employees; clustered standard errors in parentheses: ${ }^{*}$ statistical significance at $10 \%,{ }^{* *}$ at $5 \%,{ }^{* * *}$ at $1 \%$.

Source: Authors' elaboration on RIL 2018 data 
Table 6. OLS estimate of a linear regression equation. Dependent variable: Average number of 14.0 investments (I)

\begin{tabular}{|c|c|c|c|c|}
\hline & (1) & $(2)$ & (3) & (4) \\
\hline & $\mathrm{b} / \mathrm{se}$ & $\mathrm{b} / \mathrm{se}$ & $\mathrm{b} / \mathrm{se}$ & $\mathrm{b} / \mathrm{se}$ \\
\hline \multirow[t]{2}{*}{ Share of firms with graduate management } & $0.339 * *$ & $0.333^{* *}$ & $0.325^{* *}$ & $0.346 * *$ \\
\hline & $(0.140)$ & $(0.140)$ & $(0.140)$ & (0.139) \\
\hline \multirow[t]{2}{*}{ Share of firms with high-school management } & 0.157 & 0.139 & 0.136 & 0.149 \\
\hline & $(0.109)$ & (0.108) & $(0.109)$ & $(0.104)$ \\
\hline \multirow[t]{2}{*}{ Share of family firms } & $-0.349 *$ & $-0.352^{*}$ & $-0.352 *$ & $-0.336^{*}$ \\
\hline & $(0.194)$ & $(0.195)$ & $(0.196)$ & $(0.191)$ \\
\hline \multirow[t]{2}{*}{ Share of firms with RSA (union representatives) } & 0.201 & 0.181 & 0.179 & 0.179 \\
\hline & $(0.210)$ & $(0.213)$ & $(0.214)$ & $(0.210)$ \\
\hline \multirow[t]{2}{*}{ Share of firms with RSU (union representatives) } & -0.235 & -0.257 & -0.246 & -0.229 \\
\hline & $(0.204)$ & $(0.206)$ & $(0.209)$ & $(0.208)$ \\
\hline \multirow[t]{2}{*}{ Share of firms signing opting out clauses } & -0.361 & $-0.473 *$ & $-0.475^{*}$ & $-0.482 * *$ \\
\hline & $(0.250)$ & $(0.248)$ & $(0.251)$ & $(0.237)$ \\
\hline \multirow[t]{2}{*}{ Share of trained employees (log) } & $0.114^{* * *}$ & $0.116 * * *$ & $0.117 * * *$ & $0.105^{* *}$ \\
\hline & $(0.044)$ & $(0.044)$ & $(0.044)$ & $(0.044)$ \\
\hline \multirow[t]{2}{*}{ Share of firms hiring } & 0.076 & 0.056 & 0.061 & 0.052 \\
\hline & $(0.094)$ & $(0.101)$ & $(0.100)$ & $(0.100)$ \\
\hline \multirow[t]{2}{*}{ Share of firms exporting } & -0.036 & -0.053 & -0.052 & -0.081 \\
\hline & $(0.097)$ & $(0.097)$ & $(0.097)$ & $(0.098)$ \\
\hline \multirow[t]{2}{*}{ Share of firms signing agreements with foreign companies } & -0.086 & -0.097 & -0.091 & -0.004 \\
\hline & $(0.230)$ & $(0.233)$ & $(0.232)$ & $(0.227)$ \\
\hline \multirow[t]{2}{*}{ Share of firms performing outsourcing } & -0.129 & -0.306 & -0.295 & -0.454 \\
\hline & $(1.055)$ & $(0.987)$ & $(1.008)$ & $(1.002)$ \\
\hline \multirow[t]{2}{*}{ Share of firms investing in R\&D } & $0.304 * * *$ & $0.306 * * *$ & $0.303 * * *$ & $0.307^{* * *}$ \\
\hline & $(0.105)$ & $(0.104)$ & $(0.104)$ & $(0.104)$ \\
\hline \multirow[t]{2}{*}{ Share of firms introducing process innovations } & 0.128 & 0.121 & 0.118 & 0.126 \\
\hline & $(0.154)$ & $(0.153)$ & $(0.155)$ & $(0.152)$ \\
\hline \multirow[t]{2}{*}{ Share of firms introducing product innovations } & $0.579 * * *$ & $0.559 * * *$ & $0.567 * * *$ & $0.580 * * *$ \\
\hline & $(0.182)$ & (0.179) & $(0.179)$ & $(0.176)$ \\
\hline \multirow[t]{2}{*}{ Share of firms accessing to public procurement } & 0.119 & 0.109 & 0.109 & 0.115 \\
\hline & $(0.082)$ & $(0.082)$ & $(0.083)$ & $(0.083)$ \\
\hline \multirow[t]{2}{*}{ Share of firms receiving incentives } & & 0.222 & & \\
\hline & & $(0.158)$ & & \\
\hline \multirow[t]{2}{*}{ Share of firms receiving 14.0 incentives } & & & 0.211 & \\
\hline & & & $(0.168)$ & \\
\hline \multirow[t]{2}{*}{ Share of firms acceding to 'Super Ammortamento' plan } & & & & $0.440 * *$ \\
\hline & & & & $(0.207)$ \\
\hline Regional dummies & YES & YES & YES & YES \\
\hline \multirow[t]{2}{*}{ Constant } & 0.213 & 0.260 & 0.255 & 0.231 \\
\hline & $(0.260)$ & $(0.259)$ & $(0.260)$ & $(0.256)$ \\
\hline Number of observations & 280 & 280 & 280 & 280 \\
\hline Adj. R-Square & 0.429 & 0.434 & 0.433 & 0.443 \\
\hline
\end{tabular}

Notes: controls include average firm size, average firm value added and share of firms hiring employees; clustered standard errors in parentheses: ${ }^{*}$ statistical significance at $10 \%,{ }^{* *}$ at $5 \%,{ }^{* * *}$ at $1 \%$.

Source: Authors' elaboration on RIL 2018 data 
Table 7. OLS estimate of a linear regression equation. Dependent variable: Average number of I4.0 investments (II)

\begin{tabular}{|c|c|c|c|c|}
\hline & (1) & $(2)$ & (3) & (4) \\
\hline & $\mathrm{b} / \mathrm{se}$ & $\mathrm{b} / \mathrm{se}$ & $\mathrm{b} / \mathrm{se}$ & $\mathrm{b} / \mathrm{se}$ \\
\hline \multirow[t]{2}{*}{ Share of firms with graduate management } & -0.001 & -0.003 & -0.004 & 0.023 \\
\hline & $(0.142)$ & $(0.140)$ & $(0.141)$ & $(0.141)$ \\
\hline \multirow[t]{2}{*}{ Share of firms with high-school management } & -0.120 & -0.126 & -0.131 & -0.106 \\
\hline & $(0.100)$ & $(0.099)$ & $(0.100)$ & $(0.098)$ \\
\hline \multirow[t]{2}{*}{ Share of family firms } & $-0.369 * *$ & $-0.380 * *$ & $-0.366 * *$ & $-0.329 *$ \\
\hline & $(0.177)$ & $(0.180)$ & $(0.180)$ & $(0.173)$ \\
\hline \multirow[t]{2}{*}{ Share of firms with RSA (union representatives) } & $0.348^{*}$ & $0.328^{*}$ & $0.329 *$ & $0.333^{*}$ \\
\hline & $(0.193)$ & $(0.193)$ & $(0.192)$ & $(0.187)$ \\
\hline \multirow[t]{2}{*}{ Share of firms with RSU (union representatives) } & 0.233 & 0.247 & 0.263 & $0.299 *$ \\
\hline & $(0.176)$ & $(0.177)$ & $(0.182)$ & $(0.173)$ \\
\hline \multirow[t]{2}{*}{ Share of firms signing opting out clauses } & $-0.660 * *$ & $-0.862 * * *$ & $-0.878 * * *$ & $0.883 * * *$ \\
\hline & $(0.277)$ & $(0.269)$ & $(0.274)$ & $(0.243)$ \\
\hline \multirow[t]{2}{*}{ Share of trained employees (log) } & $0.105 * * *$ & $0.099 * * *$ & $0.097 * * *$ & $0.079 * *$ \\
\hline & $(0.034)$ & $(0.034)$ & $(0.034)$ & $(0.034)$ \\
\hline \multirow[t]{2}{*}{ Share of firms hiring } & $0.234 * *$ & $0.207^{*}$ & $0.211^{*}$ & $0.203^{*}$ \\
\hline & $(0.117)$ & (0.121) & $(0.120)$ & $(0.118)$ \\
\hline \multirow[t]{2}{*}{ Share of firms exporting } & -0.027 & -0.045 & -0.046 & -0.080 \\
\hline & $(0.095)$ & $(0.094)$ & $(0.094)$ & $(0.092)$ \\
\hline \multirow[t]{2}{*}{ Share of firms signing agreements with foreign companies } & -0.027 & -0.026 & -0.026 & 0.070 \\
\hline & $(0.209)$ & $(0.215)$ & $(0.216)$ & $(0.196)$ \\
\hline \multirow[t]{2}{*}{ Share of firms performing outsourcing } & -0.904 & $-1,175$ & $-1,126$ & $-1,218$ \\
\hline & $(0.983)$ & $(0.904)$ & $(0.913)$ & $(0.935)$ \\
\hline \multirow[t]{2}{*}{ Share of firms investing in R\&D } & 0.091 & 0.106 & 0.103 & 0.100 \\
\hline & $(0.095)$ & $(0.094)$ & $(0.094)$ & $(0.093)$ \\
\hline \multirow[t]{2}{*}{ Share of firms introducing process innovations } & 0.119 & 0.109 & 0.105 & 0.118 \\
\hline & $(0.194)$ & $(0.191)$ & $(0.192)$ & $(0.186)$ \\
\hline \multirow[t]{2}{*}{ Share of firms introducing product innovations } & $0.523 * *$ & $0.510 * *$ & $0.518^{* *}$ & $0.542 * * *$ \\
\hline & (0.206) & (0.200) & $(0.201)$ & (0.195) \\
\hline \multirow[t]{2}{*}{ Share of firms accessing to public procurement } & $0.219 * *$ & $0.217^{* *}$ & $0.226^{* *}$ & $0.216^{* *}$ \\
\hline & $(0.091)$ & $(0.091)$ & $(0.093)$ & $(0.091)$ \\
\hline \multirow[t]{2}{*}{ Share of firms receiving incentives } & & $0.280^{*}$ & & \\
\hline & & $(0.145)$ & & \\
\hline \multirow[t]{2}{*}{ Share of firms receiving 14.0 incentives } & & & $0.288^{*}$ & \\
\hline & & & $(0.162)$ & \\
\hline \multirow[t]{2}{*}{ Share of firms acceding to 'Super Ammortamento' plan } & & & & $0.525^{* * *}$ \\
\hline & & & & $(0.172)$ \\
\hline Sectoral dummies & YES & YES & YES & YES \\
\hline \multirow[t]{2}{*}{ Constant } & 0.374 & 0.413 & 0.391 & 0.329 \\
\hline & $(0.253)$ & (0.255) & $(0.254)$ & $(0.247)$ \\
\hline Number of observations & 280 & 280 & 280 & 280 \\
\hline Adj. R-Square & 0.468 & 0.478 & 0.477 & 0.491 \\
\hline
\end{tabular}

Notes: controls include average firm size, average firm value added and share of firms hiring employees; clustered standard errors in parentheses: ${ }^{*}$ statistical significance at $10 \%,{ }^{* *}$ at $5 \%, * * *$ at $1 \%$.

Source: Authors' elaboration on RIL 2018 data 
Table 8. OLS estimate of a linear regression equation. Dependent variable: share of firms investing in at least one 14.0 technology by macro-regions

\begin{tabular}{|c|c|c|c|c|}
\hline & $(1)$ & $(2)$ & (3) & $(4)$ \\
\hline & Center-North & South & Center-North & South \\
\hline & $\mathrm{b} / \mathrm{se}$ & $\mathrm{b} / \mathrm{se}$ & $\mathrm{b} / \mathrm{se}$ & $\mathrm{b} / \mathrm{se}$ \\
\hline \multirow[t]{2}{*}{ Share of firms with graduate management } & $0.187^{*}$ & -0.120 & $0.213^{* *}$ & -0.119 \\
\hline & $(0.100)$ & $(0.133)$ & $(0.107)$ & $(0.133)$ \\
\hline \multirow[t]{2}{*}{ Share of firms with high-school management } & 0.092 & 0.012 & 0.112 & 0.012 \\
\hline & $(0.112)$ & $(0.105)$ & $(0.107)$ & $(0.105)$ \\
\hline \multirow[t]{2}{*}{ Share of family firms } & -0.247 & -0.212 & $-0.264^{*}$ & -0.201 \\
\hline & $(0.151)$ & $(0.158)$ & $(0.158)$ & $(0.163)$ \\
\hline \multirow[t]{2}{*}{ Share of firms with external management } & $-0.321 *$ & 0.057 & $-0.319 *$ & 0.056 \\
\hline & $(0.180)$ & $(0.229)$ & $(0.193)$ & $(0.232)$ \\
\hline \multirow[t]{2}{*}{ Share of firms with RSA (union representatives) } & $0.739 * * *$ & -0.169 & $0.655^{* * *}$ & -0.163 \\
\hline & $(0.162)$ & $(0.106)$ & $(0.184)$ & $(0.112)$ \\
\hline \multirow[t]{2}{*}{ Share of firms with RSU (union representatives) } & 0.099 & -0.378 & 0.113 & -0.381 \\
\hline & $(0.150)$ & $(0.335)$ & $(0.155)$ & $(0.337)$ \\
\hline \multirow[t]{2}{*}{ Share of firms signing opting out clauses } & 0.145 & -0.212 & 0.020 & -0.215 \\
\hline & $(0.187)$ & $(0.296)$ & $(0.191)$ & $(0.296)$ \\
\hline \multirow[t]{2}{*}{ Share of trained employees (log) } & $0.111^{* * *}$ & 0.052 & $0.106 * * *$ & 0.052 \\
\hline & $(0.039)$ & $(0.032)$ & $(0.039)$ & $(0.032)$ \\
\hline \multirow[t]{2}{*}{ Share of firms exporting } & -0.080 & -0.128 & -0.119 & -0.128 \\
\hline & $(0.082)$ & $(0.112)$ & $(0.081)$ & $(0.112)$ \\
\hline \multirow[t]{2}{*}{$\begin{array}{l}\text { Share of firms signing agreements with } \\
\text { foreign companies }\end{array}$} & 0.005 & -0.201 & 0.024 & -0.199 \\
\hline & $(0.149)$ & $(0.245)$ & $(0.145)$ & $(0.246)$ \\
\hline \multirow[t]{2}{*}{ Share of firms performing outsourcing } & -0.149 & $-1.483 * *$ & -0.136 & $-1.541 * *$ \\
\hline & $(0.836)$ & $(0.646)$ & $(0.871)$ & $(0.671)$ \\
\hline \multirow[t]{2}{*}{ Share of firms investing in R\&D } & $0.155^{*}$ & $0.196 * *$ & $0.154^{*}$ & $0.198^{* *}$ \\
\hline & $(0.081)$ & $(0.077)$ & $(0.079)$ & $(0.079)$ \\
\hline \multirow[t]{2}{*}{ Share of firms introducing process innovations } & 0.027 & 0.156 & 0.025 & 0.155 \\
\hline & $(0.130)$ & $(0.149)$ & $(0.131)$ & $(0.150)$ \\
\hline \multirow[t]{2}{*}{ Share of firms introducing product innovations } & $0.415 * * *$ & $0.431 * *$ & $0.444 * * *$ & $0.427 * *$ \\
\hline & $(0.111)$ & $(0.181)$ & $(0.111)$ & $(0.183)$ \\
\hline \multirow[t]{2}{*}{ Share of firms accessing to public procurement } & 0.057 & 0.092 & 0.053 & 0.090 \\
\hline & $(0.068)$ & $(0.094)$ & $(0.069)$ & $(0.094)$ \\
\hline \multirow[t]{2}{*}{ Share of firms using 'Super Ammortamento' plan } & & & 0.316 & 0.050 \\
\hline & & & $(0.218)$ & $(0.194)$ \\
\hline \multirow[t]{2}{*}{ Constant } & 0.233 & 0.290 & 0.265 & 0.282 \\
\hline & $(0.185)$ & $(0.243)$ & $(0.192)$ & $(0.244)$ \\
\hline Number of observations & 168 & 112 & 168 & 112 \\
\hline Adj. R-Square & 0.447 & 0.376 & 0.466 & 0.369 \\
\hline
\end{tabular}

Notes: controls include average firm size, average firm value added and share of firms hiring employees; clustered standard errors in parentheses:

${ }^{*}$ statistical significance at $10 \%, * *$ at $5 \%, * * *$ at $1 \%$.

Source: Authors' elaboration on RIL 2018 data 
As a further test, we explore the correlations between sectoral-regional features and the average number of 14.0 investments, with 0 being the lowest value - when all firms in the sectorregion do not invest in enabling techs - and 5 the highest value - all firms of the sector-region invest in all 14.0 type of techs (Internet of Things, Robotics, Big data analytics, Augmented reality and Cybersecurity). To some extent, Table 6 and 7 shed lights on those factors influencing the simultaneous adoption of 14.0 technologies and therefore predicting at the sectoral-regional level the prevalence of a multi-adoption model.

The share of family-owned firms and the share of trained employees still show, respectively, a negative and positive correlation with the incidence of a multi-technology adoption strategy, both when we account for regional characteristics (Table 6) and when we account for sectoral features (Table 7). The positive association between the share of firms introducing product innovations and the number of 14.0 investments is also confirmed, while the share of firms investing in R\&D activities is positively correlated with the incidence of multiple 14.0 investments when controlling for region-specific factors (Table 6). As shown in Table 4 and 5, a higher share of firms having trade union representatives (RSA) positively correlates with a higher number of 14.0 technologies when controlling for sectoral specific characteristics (Table 7).

However, the exploration of the determinants of a multi-technology adoption model at the sectoral-regional level suggests the significance of two further features concerning both the corporate governance structure of firms and the type of prevailing industrial relations. These are: (i) the share of firms having a management with a tertiary education level which positively relates to the adoption of more than one 14.0 tech; (ii) the share of firms signing opt-out clauses that are derogation clauses in sectoral/national collective agreements. The higher the share of firms derogating, the lower the average number of 14.0 investments realized by each firm at the sectoralregional level ${ }^{12}$. Opt-out clauses indicate a noncollaborative trade union-management type of environment at the workplace level.

Controlling for sector specific effects (Table 7), three further sectoral-regional features emerge as significant drivers of multi-technology adoption: (i) the share of firms hiring employees; (ii) the share of firms with public procurement contracts (share of enterprises providing products or services to the public administration) and (iii) the share of firms that have received a subsidy for general investments (column 2) or for a specific investment related to the 'Piano Nazionale Impresa 4.0' (column 3).

Finally, Table 8 shows the results of the same models presented in Tables 4 and 5 (without the inclusion of regional and sectoral dummies) for Southern and Central-North Italian regions. The main drivers are still significant when we break down the sample in macro-regions. However, patterns related to corporate governance and availability of a trained workforce lose significance in the South.

Outsourcing and introducing new enabling technologies appear to be substitute strategies, and indeed the presence of companies outsourcing production significantly compresses the share of 14.0 adopters at the sector-region level when focusing on the South of Italy. Conversely, the share of firms adopting product innovations and investing in R\&D is always significant and positively associated to the sectoral-territorial incidence of 14.0 both in Northern and Southern Italy.

\section{Conclusions}

What can we conclude from the evidence produced in these empirical analyses? First of all, the general levels of diffusion of the new digital technologies are modest. Secondly, the strong heterogeneity characterizing sectors and regions in the Italian context is fully reflected also in the diffusion patterns of such new technologies. This

12 Opt-out clauses provide companies through various kinds of derogation the possibility to deviate from pay or other type of norms set under inter-sectoral or sectoral agreements. The reasoning behind such deviations is that they are an instrument that may permit companies to overcome temporary economic difficulties without resorting to (mass) layoffs (Eurofound). In Italy derogation clauses are not applied with respect to wages, however they are used when firms are more likely to experience financial crises. 
does not come as a surprise given the structure and evolution of the Italian regional economies in Europe over the last century (Viesti 2021a). There is indeed strong path-dependence in the trajectories of production upgrading for those sectors that are more inclined to introduce further innovations. However, against this background, some indications can be found in the data suggesting that the diffusion of new digital technologies has been triggered in most sectors and regions. Regarding the sectoral and geographical profile of these diffusion patterns, services do not appear to lag behind manufacturing in terms of adoption rates (arguably due to the role of cybersecurity in the ICT sector), while showing less geographical dispersion than manufacturing between North and South.

The emergent evidence on the performance effects of Industry 4.0 indicates that firms derive productivity gains from adoption (Cirillo et al. 2021), and that the policy incentive scheme that recently subsidized 14.0 investments in Italy was successful in lowering the financial barriers to adoption faced by firms (Cirillo et al. 2020a). This was, however, not sufficient to eliminate the enduring divides in productive capacities found across geographical areas. As clearly highlighted by Bratta et al. (2020), the hyperdepreciation measure introduced by Industry 4.0 National Plan concerned about 7 billion euros of private investments, out of which $83 \%$ originated from the manufacturing sector and the majority of recipient firms were small- and medium-sized, located in Northern regions ${ }^{13}$. In line with our results, and working on the entire population of Italian companies, the authors highlight how firms that invested in (subsidized) digital technologies in 2017 were ex-ante more productive, more likely to invest in R\&D and in the acquisition of machinery and equipment, and had higher returns on investments as well as lower levels of indebtedness. Indeed, one should bear in mind that eligibility for the fiscal incentive was granted to all firms with a registered office in Italy, regardless of their business activities or company size, and there was no cap on the amount of investments benefitting from the tax depreciation allowance. This made the Industry 4.0 Plan a 'neutral' policy scheme that was unlikely by design to revert the long-term industrial specialization of regions or to re-orient the technological path of laggard regions.

Furthermore, it should be acknowledged that the Industry 4.0 Plan was also 'neutral' from a technological point of view since firms have received money to invest in new assets without a specific targeted approach (see the case of the super-depreciation scheme). Firms were able to adopt those technologies that are more suitable to interact with their specific technological endowment, internal knowledgebase, organizational capabilities or other idiosyncratic characteristics. In this respect, those firms that had already undertaken an innovationoriented trajectory may be more responsive to the adoption of new digital technologies and thus to the incentives vis-à-vis those companies characterized by less dynamic innovative patterns.

All in all, our results suggest that sectoral and geographic agglomerations of adopters are associated with robust innovation activities and good human capital endowments. We would interpret these two factors as pre-conditions and key elements for the adoption. Interestingly, our results also point to the importance of institutional and organizational factors as facilitators of diffusion and it is plausible that the direction of causes and effects goes from governance to digitalization rather than the other way round. The broader picture emerging from the data highlights the role of skills, which are arguably as important as general (ICT) infrastructure in favoring the adoption of new digital technologies. On this basis, the different coverage degree of digital infrastructure among North and South geographical areas may represent an ex ante barrier to the diffusion of new digital technologies that may exacerbate, in turns, regional divergences in terms of adoption rates. Indeed, along with the fiscal incentives for 14.0

13 It should be acknowledged that such amount is significantly below the ex-ante estimate of the Italian Government of around 10 billion euros (Bratta et al. 2020). 
technologies, strong investment programs for a widespread diffusion of key infrastructures, such as broadband and optical fiber, across different regions should arguably be implemented in order to re-shape divergent technological trajectories of the Northern and Southern regions, and to facilitate digitalization throughout the Italian productive structure.

Overall, the experience of the incentive scheme points to the importance of more targeted innovation policy measures with precise objectives on which economic activities to relaunch and for a more active industrial policy (Mazzucato 2018; Pianta et al. 2020; Pianta 2021). Indeed, industrial policies more than pure incentive schemes can be used to reduce geographical disparities which are often the result of declining filières and weak sectoral specialization of 'peripheral' regions. The need remains to strengthen regional innovation systems and shape the policy mix in such a way as to coordinate investments plans and avoid fragmented interventions of highly uneven impact. Considering the crisis events tend to exacerbate disparities between 'core' e 'periphery'14, this is especially relevant in light of the opportunities provided by the Italian National Recovery and Resilience Plan, which includes the objective to foster digital capabilities by means of fiscal incentive schemes ${ }^{15}$ without addressing the problem of resource allocation criteria for the territorial distribution of funds (Viesti 2021b).

At the time of writing, the economic consequences of the Covid-19 pandemic are unfolding rapidly, and the upgrading of the industrial capacity of the Italian economy through new digital technologies becomes clearly urgent. As shown by the ad hoc survey run by the Italian National Statistical Office (2020) on the situation and prospects of enterprises in the emergency of Covid-19, the use of technology has had a major boost since the Covid crisis, with an acceleration in the digital transformation of companies and a change in key business processes such as internal communication within the company (also in a context of widespread smart working), external communication and the marketing channels for products and services. This impact has obviously been highly heterogeneous across sectors and company sizes, and strongly dependent on prior diffusion. The upgrading of digital capabilities in the economic system and the spread of ICTs and innovation even in backward regions would be particularly useful for new adopters of digital technologies, and not only for persistent innovators, so that more firms can be included in the ongoing restructuring of local and global value chains. Value chains are showing concurrent processes of transformation that are themselves more and more dependent on digital technologies able to connect in a modular but integrated way different phases of production and service delivery. They may therefore play a key role not only in the short-term recovery process, but also in the long-term development of regional competitive advantage. In this regard, an integrated approach between industrial, fiscal, public demand, education and labour policies, is crucial to reduce the opportunities for financial speculation and the transfer of businesses, research and production abroad, and instead to give priority to the real economy and to the expansion of skilled employment (Cresti et al. 2020).

To conclude, in this contribution we have tried to shed new light on the uneven distribution of investments in new enabling technologies across Italian regions and sectors, on the interplay between 14.0 policy scheme and adoption rates, and, ultimately on the main drivers of structural change. We have not addressed the role of heterogeneity in firm performances within regions and sectors, and the coexistence in the same region/sector of leading and lagging-behind firms. An increasing dispersion in firm performances might play a crucial role in explaining the developmental trajectories of 'core' vs. 'peripheral' areas, and therefore deserves attention in future research.

14 See for example Mina and Santoleri (2021) for a detailed analysis of the effect of the 2008 crisis on firms across European regions.

15 See Mission 1, Component 2 - Digitisation, innovation and competitiveness in the production system of the Italian PNRR. 


\section{References}

Acemoglu D., Lelarge C., Restrepo P. (2020), Competing with robots. Firm-level evidence from France, AEA Papers and Proceedings, 110, pp.383-388

Bratta B., Romano L., Acciari P., Mazzolari F. (2020), The Impact of Digitalization Policies. Evidence from Italy's Hyperdepreciation of Industry 4.0 Investments, DF Working Paper n.6, Roma, MEF <https://bit.ly/3Fo3ntu>

Bugamelli M., Cannari L., Lotti F., Magri S. (2012), The Innovation Gap of Italy's Production System. Roots and Possible Solutions, Questioni di economia e finanza n.121, Roma, Banca d'Italia <https://bit.ly/3iFr7PX>

Bugamelli M., Messori M., Monducci R. (2020), La produttività delle imprese italiane. Andamento, determinanti e proposte per un rilancio, Economia Italiana, n.2, pp.5-16

Cirillo V., Fanti L., Mina A., Ricci A. (2021), Digital technologies and firm performance. Industry 4.0 in the Italian economy, Inapp Working Paper n.61, Roma, Inapp

Cirillo V., Fanti L., Mina A., Ricci A. (2020a), Digitizing Firms. Skills, Work Organization and the Adoption of New Enabling Technologies, Inapp Working Paper n.53, Roma, Inapp

Cirillo V., Rinaldini M., Staccioli J., Virgillito M.E. (2020b), Technology vs. Workers. The Case of Italy's Industry 4.0 Factories, Structural Change and Economic Dynamics, 56, issue C, pp.166-183

Costa S., De Santis S., Dosi G., Monducci R., Sbardella A., Virgillito M.E. (2020), Alle radici della stagnazione. Una tassonomia della struttura produttiva italiana, Economia Italiana, n.2, pp.73-122 <https://bit.ly/3lhkWmT>

Cresti L., Lucchese M., Pianta M. (2020), An industrial policy after the coronavirus pandemic in Italy, L'industria, Rivista di economia e politica industriale, 51, n.4, pp.607-627 <DOI 10.1430/98705>

Domini G., Grazzi M., Moschella D., Treibich T. (2021), Threats and opportunities in the digital era. Automation spikes and employment dynamics, Research Policy, 50, n.7, article 104137

Dosi G., Grazzi M., Tomasi C., Zeli A. (2012), Turbulence underneath the big calm? The micro-evidence behind Italian productivity dynamics, Small Business Economics, 39, n.4, pp.1043-1067

Dosi G., Guarascio D., Ricci A., Virgillito M.E. (2019), Neodualism in the Italian business firms. Training, organizational capabilities, and productivity distributions, Small Business Economics, 57, n.1, pp.167-189

European Commission (2018), International Digital Economy and Society Index 2018. SMART 2007/0052. Final Report, Luxembourg, Publications Office of the European Union

Gaddi M., Garbellini N., Garibaldo F. (eds.) (2018), Industry 4.0 and its Consequences for Work and Labour. Field research report on the implementation of Industry 4.0 in a sample of Italian companies, Bologna, Fondazione Sabattini

Gaddi M., Garibaldo F., Garbellini N. (2020), The Italian Experience in Implementing Industry 4.0, UCJC Business and Society Review, 17, n.2, pp.52-69

Gal P., Nicoletti G., Renault T., Sorbe S., Timiliotis C. (2019), Digitalisation and productivity. In search of the holy grail Firm-level empirical evidence from EU countries, OECD Economics Department Working Papers n.1533, Paris, OECD Publishing <https://bit.ly/3AIVTDI>

Garibaldo F. (2017), On industry 4.0 - Position paper, Bologna, Fondazione Sabattini

Graetz G., Michaels G. (2018), Robots at work, Review of Economics and Statistics, 100, n.5, pp.753-768

Kagermann H., Wahlster W., Helbig J. (2013), Securing the future of German manufacturing industry. Recommendations for implementing the strategic initiative INDUSTRIE 4.0. Final report of the Industrie 4.0 Working Group, Munich, Acatech - National Academy of Science and Engineering <https://bit.ly/3AnG5Ru>

Keune M. (2011), Decentralizing Wage Setting in Times of Crisis? The regulation and use of wage-related derogation clauses in seven European countries, European Labour Law Journal, 2, n.1, pp.86-95

Koch M., Manuylov I., Smolka M. (2021), Robots and Firms, The Economic Journal, 131, n.638, pp.2553-2584<https://bit.ly/2ZmgSsY>

Istat (2020), Situazione e prospettive delle imprese nell'emergenza sanitaria Covid-19, Statistiche Report, dicembre 2020 $<$ https://bit.ly/2WIJOjo>

Istat (2018), Innovazione, nuove tecnologie e occupazione, in Istat, Rapporto sulla competitività dei settori produttivi. Edizione 2018, Roma, Istat, pp.55-101 <https://bit.ly/3mwshyn>

Istat (2017), La performance congiunturale dei settori produttivi, in Istat, Rapporto sulla competitività dei settori produttivi. Edizione 2017, Roma, Istat, pp.33-40 <https://bit.ly/3DbYnGy>

Mazzucato M. (2018), Mission-oriented innovation policies. Challenges and opportunities, Industrial and Corporate Change, 27, n.5, pp.803-815

Martinelli A., Mina A., Moggi M. (2021), The enabling technologies of industry 4.0. Examining the seeds of the fourth industrial revolution, Industrial and Corporate Change, 30, n.1, pp.161-188 
SINAPPSI I Connessioni tra ricerca e politiche pubbliche I Anno XI n. 2/2021 | Rivista quadrimestrale dell'INAPP

Mina A., Santoleri P. (2021), The effect of the Great Recession on the employment growth of young vs. small firms in the Eurozone, Structural Change and Economic Dynamics, 56, issue C, pp.184-194

MISE- Ministero dello Sviluppo Economico (2018), La diffusione delle imprese 4.0 e le politiche. Evidenze 2017, Roma, MISE $<$ https://bit.ly/3IIFURI>

Pardi T. (2019), Fourth industrial revolution concepts in the automotive sector: performativity, work and employment, Journal of Industrial and Business Economics, 46, n.3, pp.379-389 <DOI 10.1007/s40812-019-00119-9>

Pianta M. (2021), La politica industriale al tempo del PNRR, // Mulino, 70, n.2, pp.152-162

Pianta M., Lucchese M., Nascia L. (2020), The policy space for a novel industrial policy in Europe, Industrial and Corporate Change, 29, n.3, pp.779-795

Russo M., Pavone P., Cetrulo A. (2019), Conflict and Participation in Bargaining at Company Level. The Lamborghini Case, Economia \& lavoro, 53, n.1, pp.53-74

Viesti G. (2021a), Centri e periferie. Europa, Italia, Mezzogiorno dal XX al XXI secolo, Roma-Bari, Laterza

Viesti G. (2021b), II PNRR determinerà una ripresa dello sviluppo?, // Mulino, 7 giugno <https://bit.ly/3f7ySMO>

Vivarelli M. (1995), The economics of technology and employment, Cheltenham UK, Edward Elgar Publishing

Vivarelli M., Pianta M. (eds.) (2000), The employment impact of innovation. Evidence and policy, London, Routledge 


\begin{abstract}
Valeria Cirillo
valeria.cirillo@uniba.it

Associate Professor in Economics at the Department of Political Science of the University of Bari Aldo Moro and external affiliate at the Institute of Economics of the Scuola Superiore Sant'Anna in Pisa. Previously, she was Researcher in Applied Economics at the National Institute for Public Policy Analysis (Inapp); from 2014 to 2017 post-doctoral researcher at the Institute of Economics of Scuola Superiore Sant'Anna in Pisa and research fellow at the Department of Statistical Sciences of Sapienza University of Rome. In 2019 she edited for the Journal of Industrial and Business Economics (Springer) the Special issue Digitalizing Industry? Labor, Technology and Work Organization.
\end{abstract}

\title{
Lucrezia Fanti
}

I.fanti.ext@inapp.org

Postdoctoral researcher at the National Institute for Public Policy Analysis (Inapp) in Rome and external affiliate researcher at the Scuola Superiore Sant'Anna (SSSA) in Pisa. She obtained her PhD in Economics and Finance at the School of Economics of the Sapienza University of Rome. Her research interests include evolutionary economics, economics of innovation, growth and distribution theory, labour economics, dynamic macroeconomics and agentbased models (ABM).

\section{Andrea Mina}

andrea.mina@santannapisa.it

Associate Professor in Economics, Associate Scientific Coordinator of the Department of Excellence EMbeDS (Economics and Management in the Era of Data Science) and Pro-Rector for International Relations at Scuola Superiore Sant'Anna. Prior to his appointment at Scuola Sant'Anna, Prof. Mina was University Lecturer in Economics of Innovation at the Cambridge Judge Business School (CJBS) of the University of Cambridge. At the University of Cambridge he also served as Senior Research Associate at the Centre for Business Research (CBR), Director of Economic Studies and Fellow at St Edmund's College, and Policy Fellow at the Centre for Science and Technology (CSaP).

\section{Andrea Ricci}

an.ricci@inapp.org

Director of Research in Applied Economics and currently head of the Enterprise and Labour Unit at the National Institute for Public Policy Analysis (Inapp). He holds a Master and a PhD in Economics from the University of Rome Tor Vergata. His main research interests concern labour market and business analysis, public policy evaluation, technological change and human capital, topics on which he is the author of numerous national and international publications. In 2018, he edited for Inapp the publication of the volume Enterprises, productivity and wages: evidence for labour policies. 